\title{
Use of Daphnia spinulata Birabén, 1917 (Crustacea, Cladocera) in the aquarium trade: a potential risk of a new bioinvasion into Brazilian continental waters
}

\author{
Utilização de Daphnia spinulata Birabén, 1917 (Crustacea, Cladocera) \\ em aquariofilia: um risco em potencial de uma nova bioinvasão \\ em águas continentais brasileiras
}

Eneida Maria Eskinazi-Sant' Anna ${ }^{1}$, Mauro Schettino $^{1}$, Rosa Maria Menéndez ${ }^{2}$,

Alice de Souza Guimarães ${ }^{2}$ and Paulina Maria Maia Barbosa ${ }^{2}$

${ }^{1}$ Laboratório de Ecologia Aquática, Departamento de Biodiversidade, Evolução e Meio Ambiente - DEBIO, Instituto de Ciências Exatas e Bilógicas - ICEB, Universidade Federal de Ouro Preto - UFOP, Campus Morro do Cruzeiro, CEP 35400-000, Ouro Preto, MG, Brazil e-mail: eskinazi@iceb.ufop.br, schettinosouza@gmail.com

${ }^{2}$ Laboratório de Ecologia do Zooplâncton, Instituto de Ciencias Biologicas - ICB, Universidade Federal de Minas Gerais - UMFG, Av. Antônio Carlos, 6627, CEP 31270-901, Pampulha, Belo Horizonte, MG, Brazil e-mail: menendez@icb.ufmg.br, alice.guimaraes@gmail.com, maia@icb.ufmg.br

\begin{abstract}
In this note, we record the presence of an exotic species of cladoceran, Daphnia spinulata, used as live food in the aquarium trade in the Brazilian States of Minas Gerais and Sáo Paulo. The occurrence of this species of cladoceran in aquarium trade may represent a potential risk of a new biological invasion in Brazilian inland waters. The identification of the possible routes of bioinvasion is of paramount importance to prevent or control future invasions and to predict and reduce the potential spread of these organisms.
\end{abstract}

Keywords: zooplankton, bioinvasion, Daphnia spinulata, aquarium trade.

Resumo: Nesta nota, nós registramos a presença de uma espécie exótica de cladócero, Daphnia spinulata, utilizada como alimento vivo no comércio de aquariofilia nos Estados de Minas Gerais e São Paulo. A ocorrência desta espécie de cladócero nesta atividade comercial pode representar um risco em potencial para uma nova bioinvasão em águas continentais brasileiras. A identificação das possíveis rotas de invasão biológica é de fundamental importância para prevenir e controlar futuras invasōes, além de antecipar e conter uma possível dispersão desta espécie exótica.

Palavras-chave: zooplâncton, bioinvasão, Daphnia spinulata, aquariofilia.

Biological invasions currently represent one of the greatest worldwide threats to ecosystems. According to the Global Invasive Species Program (GISP), the introduction of species is the second greatest cause of loss of biodiversity on the planet, exceeded only by habitat degradation (Wittenberg and Cock, 2001; Simberloff, 2003). A survey by the MMA (2006) reported the confirmed occurrence of 49 invasive exotic species that affect continental waters, including crustaceans (1), aquatic macrophytes (6), microorganisms (1), molluscs (4), and fishes (37). However, other invasions of zooplankton organisms can be added to this preliminary list (Zanata et al., 2003; Bezerra-Neto et al., 2004; Maia-Barbosa et al., 2008; Simões et al., 2009).
Aquatic ecosystems are especially vulnerable to species introductions, because of their high degree of connectivity, ease of propagule dispersal, and intensive use as a transport route for materials, which aids species dispersal by shipping. In addition to these facilitating characteristics, certain activities also represent a potential opportunity for bioinvasions, and among these is the aquarium trade.

The aquarium trade is considered one of the economic activities most closely linked to the dispersal of exotic species worldwide. Associated with this activity are reported invasions of seaweeds, fish, invertebrates, parasites, and pathogens; and without special care, the expansion of this sector will result in the spread of even more pests. In addition to the spe- 
cies that are sold through the aquarium trade, which represent a potential threat of the dissemination of exotic species, the use of live food constitutes an additional route for species introduction. The larvae of many species of fishes and invertebrates will not take anything but live foods during their growth period. Zooplankton organisms have a number of features that make them useful for aquaculture, including rapid reproduction, small size, production of resting eggs, high nutritional quality, and ease of culture. Prominent among the zooplankton organisms that are most often cultured as live food in the aquarium trade are cladocerans of the genus Daphnia. These organisms are the preferred subject of this aquaculture practice, because of the group of characteristics that facilitate and encourage their cultivation, including the standardization of culture techniques that are widely known among breeders.

In this note, we record the presence of an exotic species of cladoceran, Daphnia spinulata used as live food in the aquarium trade in the Brazilian States of Minas Gerais and São Paulo. The geographical records of this cladoceran include the Southern parts of South America, and it is considered to be typical of cold waters in Argentina (Olivier, 1962). This species is typical of mesohaline waters, and can also be found in oligohaline environments (Hoffmeyer, 2004).

The main purpose of this report is to improve our understanding of the main sources of species introductions in inland waters, in order to prevent or control future invasions and to predict and reduce the potential spread of these organisms. When engaged in this effort, the main steps to undertake are, first, to identify the presence of an alien species, and to identify the vectors of their introduction. The understanding of these mechanisms may be a useful predictive tool, helping to protect aquatic ecosystems from future invaders.

Specimens of Daphnia spinulata were obtained from two aquarium hobbyists in the city of Ouro Preto, Minas Gerais State and São Paulo city, São Paulo State. This species has been cultivated for about 10 years, for use as fish food (mainly for feeding of Poecilia spp.). The species was identified from the descriptions by Olivier (1962) and Paggi (1995). For the allometric measurements, 20 individuals were analyzed by the use of an Olympus BX61 optical microscope equipped with image-analysis software. Digital images of the specimens were also obtained.

According to Olivier (1962), individuals of D. spinulata have a large body with the dorsal margin slightly convex and the ventral margin strongly curved. A row of spinules covers the dorsal border from the end of the head, continuing on the terminal spine, descending to the posterior border, and ending on the middle part of the lower border. The head is large and rounded, with short antennules in the form of a truncated cone. The postabdomen is large and triangular, with the distal part slightly convex, bearing 9 or 10 strong spines. The caudal claw is robust, with two inner and three outer pectens Figure 1. The individuals are between 1.90 and $2.40 \mathrm{~mm}$ long. The mean size of the specimens obtained in Brazil was $1.70 \mathrm{~mm}$, ranging from 1.07 to $1.85 \mathrm{~mm}$, slightly smaller than the specimens described by Olivier (1962).

The lack of efficient monitoring mechanisms and the absence of standards protocols for culturing native species can be mentioned as some of the facilitating factors that have sustained the use of exotic species in aquarium hobby activities.

Although there are no official records of the number of aquarium hobbyists who cultivate the cladoceran, it is very likely that the commercial use of $D$. spinulata is common among many aquarium hobbyists. The intense interchange of specimens between the aquarium hobbyists makes difficulty the adoption of inspection and control mechanisms. Another potential source of risk considering the commercial cultivation of D. spinulata is the discard of specimens, been in the sewerage system or directly in the aquatic ecosystems. Considering that zooplanktonic cultures usually presents high densities, even small portions of these cultures, when inappropriately discarded, can represent a dangerous source of introduction of specimens.

Until now, there are no known records of the occurrence of $D$. spinulata in the continental aquatic ecosystems of the states of Minas Gerais and São Paulo. The cladoceran D. spinulata is originally a subtropical species, whose occurrence is limited to milder climates (temperatures below $25^{\circ} \mathrm{C}$ ), which could restrict the dispersal of this species in Brazil to subtropical aquatic ecosystems (Olivier, 1962). With respect to the trophic conditions in which this species could establish itself in Brazilian continental waters, no data are available at present, and studies on this subject are ongoing. In this sense, the regular monitoring of the aquatic ecosystems represents a fundamental stage to the prevention and control of bioinvasion and to the implementation of future management actions.

The adoption of legal mechanisms to control the use of exotic species and encouragement for the rearing of native zooplankton species should be considered in any initiatives taken for the use and management of the biota of Brazilian aquatic systems. The unregulated trade presents a serious bioinvasion risk that warrants the urgent attention of regulatory bodies. 

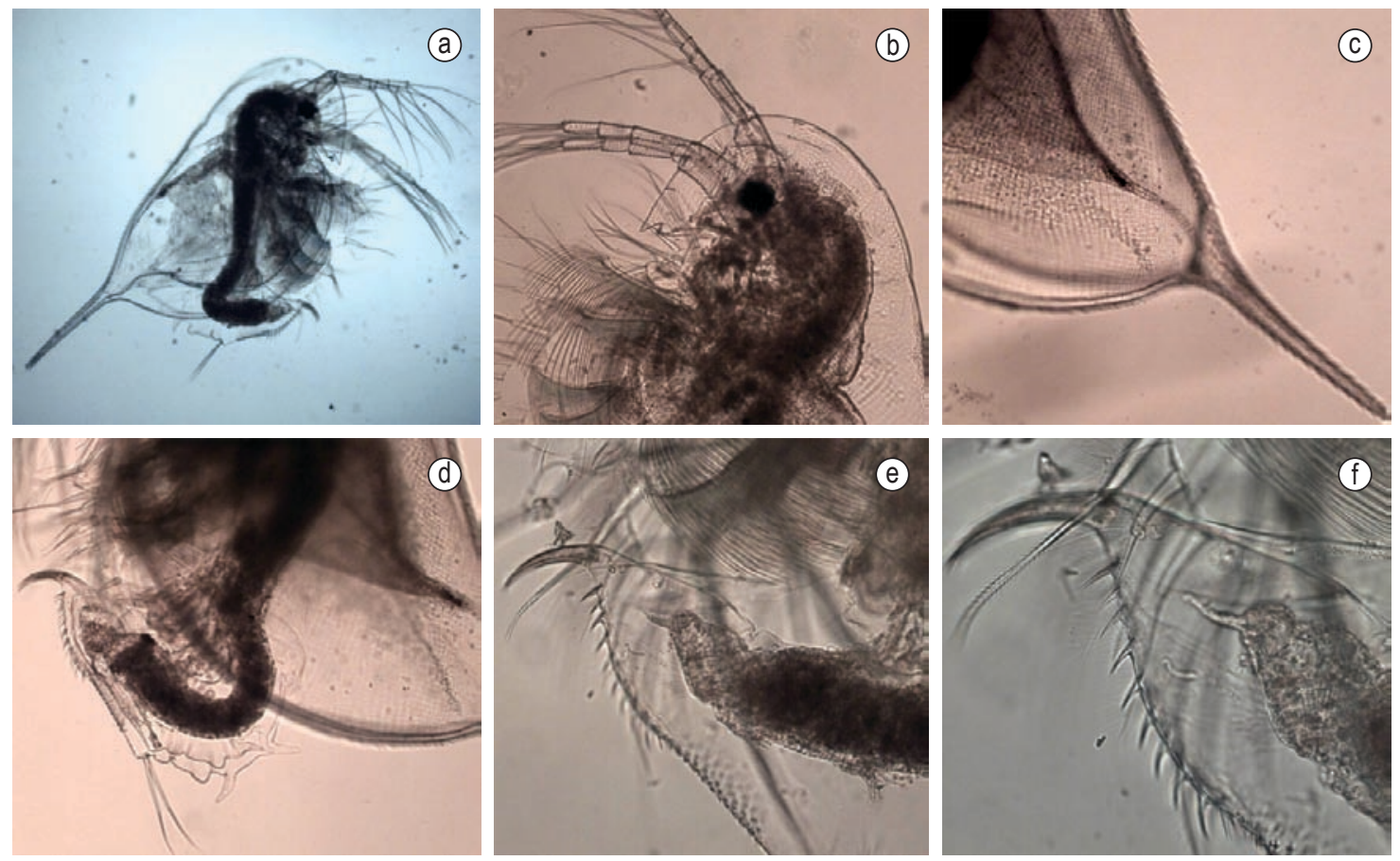

Figure 1. Daphnia spinulata specimens collected with Brazilian aquariophilists; a) General view of female (200x); b) General view of head (300x); c) Spines in the ventral carapace (400x); d) Postabdomen (300x); e) Detail of Postabdomen (350x); and f) Detail of spines of the postabdomen $(600 \times)$.

\section{Acknowledgements}

Dr. Janet Reid is thanked for correction of the language. Dr. Lourdes El Moor Loureiro kindly confirmed the specimens's identifications. I am most grateful to the anonymous reviewers which comments and suggestions greatly improved this note.

\section{References}

BEZERRA NETO, JF., AGUILA, LR., LANDA, GG. and PINTO-COELHO, RM., 2004. The exotic rotifer Kellicotia bostoniensis (Rousselet, 1908) (Rotifera: Brachionidae) in the zooplankton community in a tropical reservoir. Lundiana, vol. 5, no. 2, p. 151-153.

HOFFMEYER, MS., 2004. Decadal change in zooplankton seasonal succession in the Bahía Blanca estuary, Argentina, following introduction of two zooplankton species. Journal of Plankton Research, vol. 26, no. 2, p. 181-189.

MAIA-BARBOSA, PM., PEIXOTO, RS. and GUIMARÁES, AS., 2008. Zooplankton in littoral waters of a tropical lake: a revisited biodiversity. Brazilian Journal of Biology, vol. 68, no. 4, p. 1069-1078.

Ministério do Meio Ambiente - MMA, 2006. Espécies exóticas invasoras: situação brasileira. Brasília. $24 \mathrm{p}$.

OLIVIER, SR., 1962. Los cladóceros argentinos. Revista del Museo de La Plata, no. 7, p. 173-269.
PAGGI, JC., 1995. Crustacea Cladocera. In LOPRETTO, EC. and TELL, G. (Eds.). Ecosistemas de aguas continentales: metodologías para su estudio. La Plata: Ediciones Sur. 953 p. (vol. 3)

SIMBERLOFF, D., 2003. Erradication-preventing invasions at the outset. Weed Science, vol. 51, no. 2, p. 247-253.

SIMÓES, NR., ROBERTSON, BA., LANSAC-TÔHA, FA., TAKAHASHI, EM., BONECKER, CC., VELHO, LFM. and JOKO, CY., 2009. Exotic species of zooplankton in the Upper Paraná River Floodplain, Daphnia lumholtzi Sars, 1885 (Crustacea: Branchiopoda). Brazilian Journal of Biology, vol. 69, no. 2, p. 551-558.

ZANATA, LH., ESPÍNDOLA, ELG., ROCHA, O. and PEREIRA, RHG., 2003. First record of Daphnia lumholtzi (Sars, 1885), exotic cladoceran in São Paulo State (Brazil). Brazilian Journal of Biology, vol. 63, no. 4, p. 717-720.

WITTENBERG, R. and COCK, MJW., 2001. Invasive alien species. How to address one of the greatest threats to biodiversity: a toolkit of best prevention and management practices. Wallingford: $\mathrm{CAB}$ International. $228 \mathrm{p}$.

Received: 13 September 2009 Accepted: 03 March 2010 